\title{
OVERCOMING DORMANCY IN STORED AND RECENTLY HARVESTED Passiflora cincinnata Mast. SEEDS
}

\author{
SUPERAÇÃO DE DORMÊNCIA EM SEMENTES DE Passiflora cincinnata Mast. \\ ARMAZENADAS E RECÉM-COLHIDAS
}

\author{
Regiana dos Santos MOURA ${ }^{1}$; Mauricio Antônio COELHO FILHO²; Hans Raj GHEYI ${ }^{3}$; \\ Onildo Nunes de JESUS ${ }^{2}$; Lucas Kennedy Silva LIMA ${ }^{4}$; Tatiana Goes JUNGHANS ${ }^{2}$ \\ 1. PhD Student of Agricultural Engineering, Federal University of Recôncavo of Bahia, Cruz das Almas, BA, Brasil. \\ regianna.ufpi@gmail.com; 2. Embrapa Cassava and Fruits - CNPMF, Cruz das Almas, Bahia, Brasil; 3. Visiting Professor, Federal \\ University of Recôncavo of Bahia, Cruz das Almas, BA, Brasil; 4. PhD Student of Agricultural Sciences, Federal University of \\ Recôncavo of Bahia, Cruz das Almas, BA, Brasil.
}

\begin{abstract}
The treatment of seeds using growth regulators can overcome seed dormancy and increase the emergence and development of seedlings. The objective of this research was to evaluate the effect of different concentrations of $\mathrm{GA}_{4+7}+\mathrm{N}$-(phenyl methyl)-aminopurine on the dormancy breaking of Passiflora cincinnata Mast. seeds recently harvested and stored for six years. The study was conducted in a greenhouse at Embrapa Cassava and Tropical Fruits, in completely randomized design, in a 2 x 4 factorial scheme, with the following factors: year of seed harvest (2010 and 2016) and the emergence promoter $\mathrm{GA}_{4+7}+\mathrm{N}$-(phenyl methyl)-aminopurine at four concentrations $(0 \%$; $0.03 \%$; $0.45 \%$ and $0.90 \%$ ), with 4 replicates of 25 seeds. Emergence percentage, first count, emergence speed index, number of leaves, root length, stem diameter, dry matter of shoots, roots and total, and root/shoot ratio were evaluated. The results showed that $\mathrm{GA}_{4+7}+\mathrm{N}$-(phenyl methyl)-aminopurine is recommended to overcome dormancy of Passiflora cincinnata in recently harvested seeds (2016) and increase the emergence of seedlings from seeds stored for six years in cold chamber (2010). The emergence promoter concentration of $0.03 \%$ can be used to overcome dormancy in recently harvested seeds and maintains the vigor of seeds stored for six years. Passiflora cincinnata seeds remain physiologically viable for six years and their emergence is potentiated by the use of $\mathrm{GA}_{4+7}+\mathrm{N}$-(phenyl methyl)-aminopurine.
\end{abstract}

KEYWORDS: Conservation. $\mathrm{GA}_{4+7}+\mathrm{N}$-(phenyl methyl)-aminopurine. Passion fruit. Germination.

\section{INTRODUCTION}

The vast diversity of Passifloraceae species in Brazil has great potential for utilization in pesticide production, pharmaceutical industry, cosmetics and in genetic improvement (OLIVEIRA JÚNIOR et al., 2010).

The conservation and propagation of wild species are of great interest for the genetic improvement programs, because interspecific crosses allow to incorporate genes of resistance to the diseases in commercial species (SANTOS et al., 2015; FREITAS et al., 2016) and ornamental species (SOARES et al., 2015; OCAMPO et al., 2016).

The species Passiflora cincinnata Mast., popularly known as 'maracujá-do-mato' and 'maracujá-mochila', is found in various states of Brazil, native to the semi-arid region, considered as tolerant to drought (ZUCARELI et al., 2009a) and resistant to the diseases caused by the fungus Fusarium oxysporum f. sp. passiflorae (SILVA et al., 2013), bacterial blight (Xanthomonas axonopodis pv. passiflorae) (OLIVEIRA et al., 2013), and fruit woodiness caused by cowpea apohid-borne mosaic virus - CABMV (OLIVEIRA et al., 2013).

The limiting factors for the utilization of this species, either commercially or in genetic improvement programs, include the low and nonuniform germination of its seeds. Initially, the dormancy of Passifloraceae species was assumed to be caused by mechanisms of control of the entry of water in the seed, due to the hardness of the tegument (MORLEY-BUNKER, 1980). However, the dormancy of Passiflora cincinnata seeds may not be related to this mechanism, because Zucareli (2009a) observed that this species has permeability to water, concluding that the dormancy must be related to other physiological factors of the seed.

Many authors suggest the storage for Passiflora cincinnata as a strategy to overcome dormancy (MELETTI et al., 2002); however, the storage period may be longer than two years, delaying the actions performed by the breeding improvement programs to obtain interspecific hybrids or the utilization of the species as rootstock. Pereira et al. (2011) observed $0.25 \%$ emergence in Passiflora cincinnata seeds that had not been stored, with increase of $21 \%$ in emergence after 60 days of storage under refrigeration at $10{ }^{\circ} \mathrm{C}$. According to 
the authors, it indicates the presence of dormancy in the seeds, which is overcome during the storage.

Literature results have shown the low emergence percentage of seedlings obtained from recently harvested or recently stored seeds of Passiflora cincinnata (OLIVEIRA JUNIOR et al., 2010; SANTOS et al., 2016). Hence, many researchers have used growth regulators to increase emergence percentage, e.g., Amaro et al. (2009) used $\mathrm{GA}_{4+7}$ and observed increment in germination percentage and germination speed in Passiflora cincinnata seeds, promoting dormancy breaking. However, these authors evaluated only recently harvested seeds, disregarding the effect of regulators on seeds stored for longer periods. In addition, the concentrations used by Amaro et al. (2009) were limited to a maximum of $0.05 \%$, without any indication of the potential toxic effect of $\mathrm{GA}_{4+7}$ under high concentrations of regulators.

Thus, this study aimed to evaluate the effect of different concentrations of the growth regulators $\mathrm{GA}_{4+7}+\mathrm{N}$-(phenyl methyl)-aminopurine on the dormancy breaking of Passiflora cincinnata Mast. seeds recently harvested and stored for six years.

\section{MATERIAL AND METHODS}

The experiment was installed in a greenhouse at Embrapa Cassava and Fruits, located in the municipality of Cruz das Almas-BA, Brazil (Latitude of $12^{\circ} 48^{\prime} \mathrm{S}$, Longitude of $39^{\circ} 06^{\prime} \mathrm{W}$ and altitude of $225 \mathrm{~m}$ ), in the period from March to May 2016. The temperature in the greenhouse was regulated at $28 \pm 2{ }^{\circ} \mathrm{C}$, and relative humidity at $60 \pm$ $5 \%$.

The seeds used in the experiment were of the species Passiflora cincinnata Mast., from the Active Germplasm Bank of Passiflora of the Embrapa Cassava and Fruits. Ripe fruits with lightgreen color of the epicarp were harvested in 2010 and 2016 and their seeds were extracted and washed following the recommendation of Junghans et al. (2010) and Jesus et al. (2016). The seeds were dried in the shade for 12 days and stored in cold chamber at temperature of $10 \pm 2{ }^{\circ} \mathrm{C}$, and relative air humidity was maintained at $50 \pm 5 \%$. Moisture content was estimated with three subsamples of 10 seeds by the oven method at $105^{\circ} \mathrm{C}$ (Brasil, 2009), and was equal to $8.8 \%$ in the stored seeds.

The experimental design was completely randomized, arranged in a $2 \times 4$ factorial scheme, with 4 replicates of 25 seeds, corresponding to two harvest periods, the first one in 2010 and the second one in 2016, and four concentrations of $\mathrm{GA}_{4+7}+\mathrm{N}$ - (phenyl methyl)-aminopurine $(0 \% ; 0.03 \% ; 0.45 \%$ and $0.90 \%$ ). The source of $\mathrm{GA}_{4+7}+\mathrm{N}$-(phenyl methyl)-aminopurine was the commercial product Promalin $^{\circledR}$, which is composed by $1.8 \%$ of $\mathrm{N}$ (phenyl methyl)-1H-6-aminopurine and $1.8 \%$ of $\mathrm{GA}_{4+7}$. The seeds harvested in 2010 and recently harvested (2016) were immersed in the solutions for 24 hours and then dried using paper towel.

Subsequently, the seeds were distributed on polystyrene trays with 162 cells, with capacity for $50.0 \mathrm{~mL}$, and one seed per cell was sown at depth of $1.0 \mathrm{~cm}$. The commercial substrate Vivatto ${ }^{\circledR}$ was used for seedling emergence. Irrigation was daily applied through automatic sprinklers from $7 \mathrm{~h} 00$ to 7h20 a.m.

The effects of the treatments on the emergence and initial growth of the seedlings were evaluated by calculating the first count of emergence (FC, \%) performed at 21 days after sowing (DAS); emergence percentage (E, \%), at 50 DAS; emergence speed index (ESI), with daily count until 50 days after emergence (DAE), using the following formula: $\mathrm{ESI}=\mathrm{G} 1 / \mathrm{N} 1+\mathrm{G} 2 / \mathrm{N} 2+\ldots \ldots$. $\mathrm{Gn} / \mathrm{Nn}$. (G1 = number of emerged plants and $\mathrm{N} 1=$ number of days after sowing) (Maguire, 1962). After stabilization of emergence, the following variables were determined: number of leaves (NL); shoot length (SL), in $\mathrm{cm}$; root length (RL), in $\mathrm{cm}$; stem diameter (SD), in $\mathrm{mm}$; shoot dry matter (SDM), in $\mathrm{mg}$; root dry matter (RDM), in $\mathrm{mg}$; total dry matter (TDM), in mg; and root dry matter/shoot dry matter ratio (RDM/SDM). The parameters RDM and SDM were determined after drying the material in a forced-air oven regulated at $65^{\circ} \mathrm{C}$ for $72 \mathrm{~h}$, and weighed on analytical scale.

The data were subjected to analysis of variance, using the $\mathrm{F}$ test $(\mathrm{p} \leq 0.05)$ to verify the effects of the isolated factors and their interactions. The means of the treatments were compared by Tukey test, considering a probability level of up to 0.05 .

\section{RESULTS AND DISCUSSION}

The interaction between factors (year $\mathrm{x}$ concentrations) was significant for all studied variables, except shoot length and root dry matter/shoot dry matter ratio, which were significantly affected by the concentration of $\mathrm{GA}_{4+7}$ $+\mathrm{N}$ - (phenyl methyl)-aminopurine and year of collection, while the root dry matter/shoot dry matter ratio was affected only by year of collection, with $46.42 \%$ superiority for seeds harvested in 2010 (Table 1). 
Table 1. Summary of the analysis of variance for the morphophysiological characteristics of Passiflora cincinnata seeds harvested in different periods and subjected to different concentrations of $\mathrm{GA}_{4+7}+$ $\mathrm{N}$-(phenyl methyl)-aminopurine

\begin{tabular}{|c|c|c|c|c|c|c|c|c|c|c|c|}
\hline \multicolumn{12}{|c|}{ Mean square } \\
\hline $\begin{array}{l}\text { Source of } \\
\text { variation }\end{array}$ & $\mathrm{FC}$ & E & ESI & NL & SL & RL & SD & SDM & RDM & TDM & RDM/SDM \\
\hline Year $(Y)$ & $16.60^{* *}$ & $49.50^{* *}$ & $9.66^{* *}$ & $22.3^{* *}$ & $3.0^{\mathrm{ns}}$ & $10.13^{* * *}$ & $2.15^{\mathrm{ns}}$ & $8.06^{* *}$ & $33.14^{* * *}$ & $13.66^{* *}$ & $25.12^{* * *}$ \\
\hline Conc. (C) & $29.10^{* *}$ & $60.90^{* *}$ & $46.40^{* *}$ & $8.44^{* *}$ & $5.47^{* *}$ & $5.57^{* *}$ & $8.31^{* *}$ & $13.77^{* *}$ & $15.0^{* *}$ & $16.76^{* *}$ & $3.16^{*}$ \\
\hline Y x C & $3.49^{*}$ & $14.70^{* * *}$ & $7.23^{* *}$ & $5.08^{* *}$ & $4.11^{\mathrm{ns}}$ & $5.14^{* *}$ & $4.98^{* *}$ & $10.85^{* *}$ & $5.04^{* *}$ & $11.85^{* *}$ & $2.35^{\mathrm{ns}}$ \\
\hline Error & 1.01 & 0.56 & 0.10 & 0.05 & 0.30 & 0.20 & 0.01 & 0.55 & 0.08 & 0.59 & 0.001 \\
\hline CV \% & 17.4 & 10.47 & 10.47 & 10.89 & 19.33 & 15.51 & 8.85 & 18.18 & 13.15 & 16.97 & 3.19 \\
\hline \multicolumn{12}{|c|}{ Mean } \\
\hline Year & $\%$ & $\%$ & & & $\mathrm{~cm}$ & $\mathrm{~cm}$ & $\mathrm{~mm}$ & $\mathrm{mg}$ & $\mathrm{mg}$ & $\mathrm{mg}$ & \\
\hline 2016 & $29.7 \mathrm{~b}$ & $44.0 \mathrm{~b}$ & $44.0 \mathrm{~b}$ & $6.14 \mathrm{~b}$ & $7.12 \mathrm{a}$ & $6.85 b$ & $1.46 \mathrm{a}$ & $15.85 \mathrm{~b}$ & $2.90 \mathrm{~b}$ & $18.75 b$ & $0.15 b$ \\
\hline 2010 & $43.5 \mathrm{a}$ & $64.0 \mathrm{a}$ & $64.0 \mathrm{a}$ & $7.98 \mathrm{a}$ & $8.18 \mathrm{a}$ & $9.18 \mathrm{a}$ & $1.62 \mathrm{a}$ & $19.56 \mathrm{a}$ & $5.21 \mathrm{a}$ & $24.77 \mathrm{a}$ & $0.28 \mathrm{a}$ \\
\hline
\end{tabular}

$\mathrm{ns}$, ** and *: not significant and significant at 0.01 and 0.05 probability levels, respectively. FC: first count of emergence; E: emergence percentage; ESI: emergence speed index; NL: number of leaves; SL: shoot length; RL: root length; SD: stem diameter; SDM: shoot dry matter; RDM: root dry matter; TDM: total dry matter.

The concentrations of the growth regulators affected shoot length, which was lower when the emergence promoter was not used (Figure 1A). The concentration of $0.45 \%$ led to higher RDM/SDM ratio, differing only from the concentration of $0 \%$, confirming once again the positive effect of the growth promoter (Figure 1B).

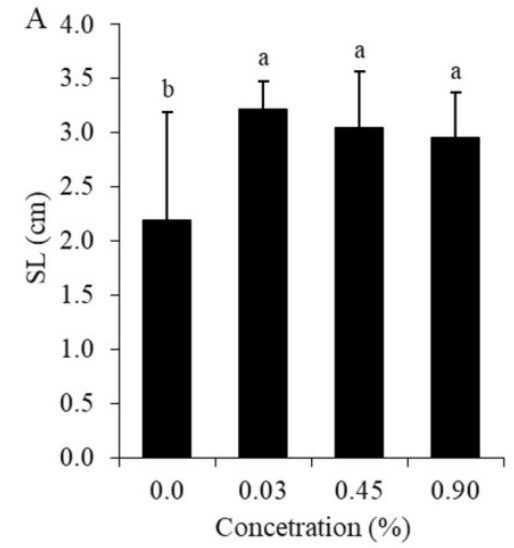

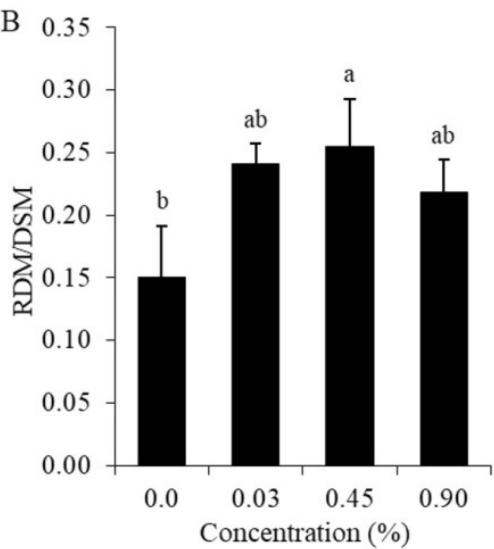

Figure 1. Effect of $\mathrm{GA}_{4+7}+\mathrm{N}$-(phenyl methyl)-aminopurine concentrations on shoot length - SL (A) and root dry matter/shoot dry matter ratio - RDM/SDM (B) of Passiflora cincinnata seedlings.

*Means followed by the same lowercase letters do not differ.

The greater growth and root matter at the growth promoter concentrations from $0.03 \%$ on can be attributed to the synergetic effect of gibberellins and cytokinin. These hormones are essential in the activation of embryo growth, activation of enzymes that degrade the starch found in the endosperm, cell division and mobilization of energy reserves to the embryo (KĘPCZYNSKI et al., 2006; MELLO et al., 2009; ZHAO, 2010; LEWAK et al., 2011; GUPTA; CHAKRABARTY, 2013; CEMBROWSKA-LECH; KEPCZYNSKI, 2015).

In the interaction between the factors, there was alteration in the variable first count of emergence for the harvest years at $0 \%$ and $0.03 \%$ concentrations of $\mathrm{GA}_{4+7}+\mathrm{N}$-(phenyl methyl)aminopurine, with $95.23 \%$ and $33.3 \%$ of superiority for the year 2010, respectively. This indicates that the dormancy of Passiflora cincinnata seeds was overcome by the six-year storage and potentiated by the low concentration $(0.03 \%)$ of the growth regulator, corroborating with the results of Oliveira Junior et al. (2010), Pereira et al. (2011) and Santos et al. (2016). Regarding the concentrations, only $0 \%$ was inferior to the others in both harvest years (Figure 2A), confirming the effect of the growth regulator. 

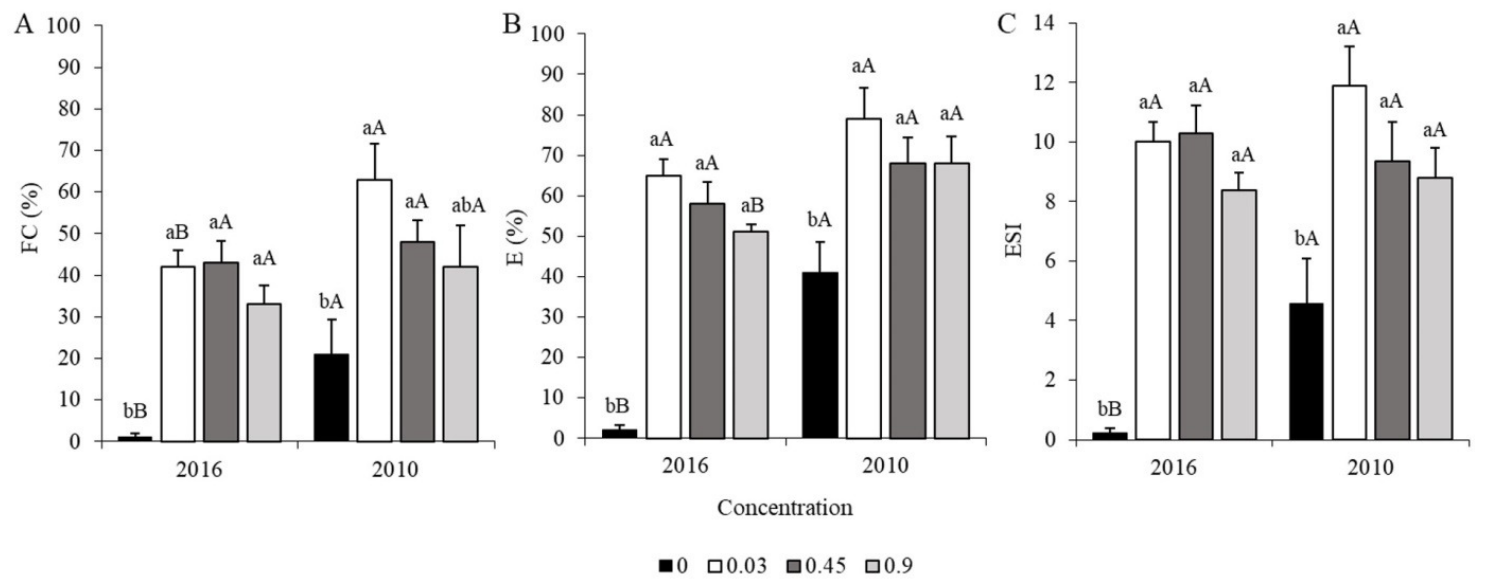

Figure 2. Effect of the interaction on first count of emergence - FC (A), emergence percentage - E (B) and emergence speed index - ESI (C) of Passiflora cincinnata seedlings obtained from seeds harvested in different periods and subjected to different concentrations of $\mathrm{GA}_{4+7}+\mathrm{N}$-(phenyl methyl)aminopurine.

*Means followed by the same letter do not differ. Lowercase letters compare the means of the concentrations for the harvest year. Uppercase letters compare the means of the concentrations between the harvest years.

Seedling emergence was lower in seeds harvested in 2016 at the concentrations $0 \%$ and $0.9 \%$, demonstrating that, either in the absence or at the highest concentration of the growth regulator, the emergence is inhibited, perhaps due to absence or toxic effects on recently harvested seeds. The other concentrations did not differ between the harvest years, emphasizing that recently harvested seeds can achieve similar emergence with the use of the emergence promoter. The effect of $\mathrm{GA}_{4+7}+\mathrm{N}-$ (phenyl methyl)-aminopurine is more evident in recently harvested seeds (year 2016), when emergence increased from $2 \%$ to $65 \%$ at the concentrations of $0 \%$ and $0.03 \%$, respectively, which corresponded to an increase of 31.5 times in seedling emergence (Figure 2B). This indicates that the regulator is more efficient than the storage, allowing the utilization of seeds from recently harvested fruits.

In the comparison between the concentrations for seedling emergence, only the control $(0 \%)$ was different, being inferior to the others in both harvest years. The result of the present study agrees with that found by Amaro et al. (2009), who observed higher germination percentage in Passiflora cincinnata (74\%) in the association of $100 \mathrm{mg}$ of $\mathrm{GA}_{4+7}+\mathrm{N}$-(phenyl methyl)-aminopurine $+100 \mathrm{mg}$ of ethephon.

On the other hand, a different result was reported by Santos et al. (2016), who evaluated the effect of $\mathrm{GA}_{3}$ on the dormancy breaking of seeds recently harvested and stored for 11 months, of different Passiflora species, including Passiflora cincinnata. These authors observed that the product did not have significant effect on seeds stored in cold chamber for 11 months, and found 65\% emergence in recently harvested seeds at the concentration of $100 \mathrm{mg} . \mathrm{L}^{-1}$, but the control treatment obtained $59.2 \%$ emergence. This result indicates that $\mathrm{GA}_{4}+7+\mathrm{N}$-(phenyl methyl)aminopurine is more indicated to overcome dormancy in freshly harvested seeds and potentiates emergence in seeds stored for six years.

The interaction between factors demonstrated that the ESI varied between the years only at the concentration $0 \%$, with lower value in recently harvested seeds (Figure 2C). For the $\mathrm{GA}_{4+7}$ concentrations, again there was only alteration at the concentration $0 \%$ for both harvest years, while at the other concentrations, similar values were observed. In general, Passiflora cincinnata seeds stored for six years (year 2010) obtained higher results compared with recently harvested seeds (Table 1). The superiority can be attributed to the absence of emergence in the treatment not subjected to $\mathrm{GA}_{4+7}+\mathrm{N}$-(phenyl methyl)-aminopurine in the recently harvested seeds (year 2016), treated only with distilled water, causing reduction in FC. However, Santos et al. (2016) obtained different results for the same species, with higher emergence $(62 \%)$ in recently harvested seeds treated with $\mathrm{GA}_{3}$, compared with seeds stored for 11 months $(28.25 \%)$.

On the other hand, Amaro et al. (2009) found low germination percentage $(20.0 \%)$ in Passiflora cincinnata seeds not treated with $\mathrm{GA}_{4+7}+$ $\mathrm{N}$-(phenyl methyl)-aminopurine. When the authors used $500 \mathrm{mg} \cdot \mathrm{L}^{-1}$, the germination percentage was $80.0 \%$, corroborating the results of the present study, in which there was positive effect of the 
growth regulators on the dormancy breaking in the seeds of this species.

The number of leaves relative to recently harvested seeds (2016) was lower than that for seeds stored for six years (2010) at the concentrations $0 \%$, $0.03 \%$ and $0.9 \%$. Among the concentrations, only the value of recently harvested seeds in the control treatment $(0 \%)$ was inferior to the others (Figure $3 \mathrm{~A})$. The results of number of leaves agree with those of Zucareli et al. (2009b), who observed greater increment in number of leaves at the concentration of $300 \mathrm{mg} \mathrm{L}^{-1}$, which corresponds to $0.03 \%$ of $\mathrm{GA}_{4+7}+\mathrm{N}$-(phenyl methyl)-aminopurine. Thus, it can be inferred that the low concentration of the growth regulator $(0.03 \%)$ is sufficient to overcome the dormancy of the seeds, because the best results for most of the analyzed variables occurred at this concentration.
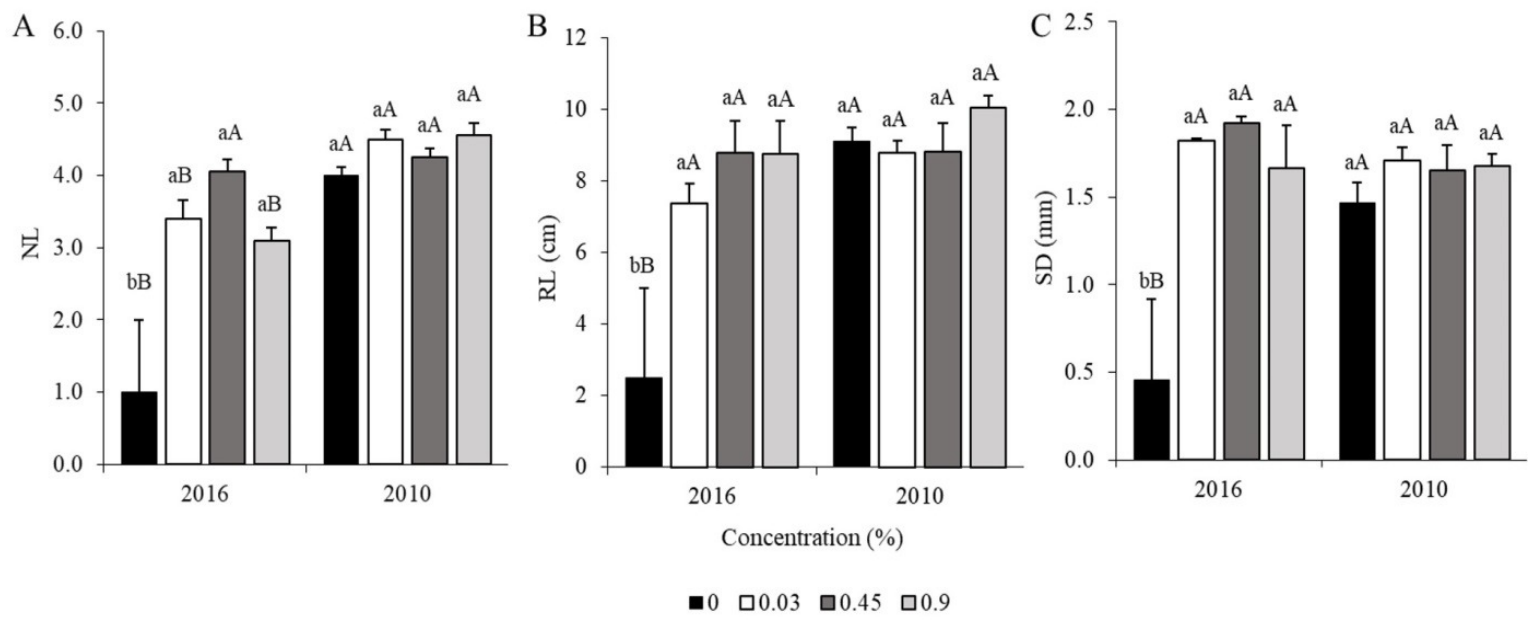

Figure 3. Effect of the interaction on number of leaves - NL (A), root length - RL (B) and stem diameter - SD (C) of Passiflora cincinnata seedlings obtained from seeds harvested in different periods and subjected to different concentrations of $\mathrm{GA}_{4+7}+\mathrm{N}$-(phenyl methyl)-aminopurine.

* Means followed by the same letter do not differ. Lowercase letters compare the concentrations for harvest year. Uppercase letters compare the means of the concentrations between the harvest years.

Root length and stem diameter were influenced by the harvest year of 2016 only at the concentration $0 \%$, with $72.49 \%$ and $69.17 \%$ of superiority for seeds harvested in 2010, respectively (Figures 3B and 3C). Regarding the concentrations, the above-mentioned variables differed only for recently harvested seeds when the emergence promoter was not used, and there was no difference for the seeds stored for six years. The results of number of leaves and stem diameter for stored seeds (2010) agree with those of Santos et al. (2016), who observed that stored seeds (11 months) did not differ between the different concentrations of $\mathrm{GA}_{3}$. Thus, the growth regulator acts by potentiating the vigor of the stored seeds, as can be observed in emergence percentage and emergence speed index (Figures 2B and $2 \mathrm{C}$ ).

The responses observed in the seeds harvested in 2016 are similar for most variables, compared with the seeds stored for six years (2010), in the treatments with $\mathrm{GA}_{4+7}+\mathrm{N}$-(phenyl methyl)aminopurine. In the control treatment, however, the stored seeds are significantly superior, corroborating with the results of Meletti et al. (2002), Pereira et al. (2011) and Junghans \& Jesus (2015), who claimed that it is necessary to store the seeds of this species for long periods to break their dormancy.

Shoot dry matter only differed in the control treatment $(0 \%)$ for both factors, years and concentrations, with inferiority for the year 2016 (Figure 4A). This must have occurred because the recently harvested seeds have physiological dormancy and the growth regulator has synergetic effect of gibberellins and cytokinin, hormones that are essential in the activation of embryo growth, promoting higher vigor and development of the plants (KĘPCZYŃSKI et al., 2006; MELLO et al., 2009; ZHAO, 2010; LEWAK, 2011; GUPTA; CHAKRABARTY, 2013; CEMBROWSKA-LECH; KEPCZYNSKI 2015).

Root dry matter and total dry matter showed similar behavior, with difference between the control $(0 \%)$ and the concentration $0.03 \%$ of the growth regulators, which led to favorable results in the seeds harvested in 2010 (Figure 4B and 4C). In the comparison between concentrations, only the control $(0 \%)$ in the recently harvested seeds differed, being inferior to the others.

The results of shoot dry matter and root dry matter corroborate those observed by Santos et al. 
(2016), who used four concentrations of $\mathrm{GA}_{3}$ and observed in recently harvested Passiflora cincinnata seeds greater increments in shoot dry matter at the concentration of $500 \mathrm{~g} \mathrm{~L}^{-1}$ and root dry matter at the concentration of $606.25 \mathrm{~g} \quad \mathrm{~L}^{-1}$ of $\mathrm{GA}_{3}$.
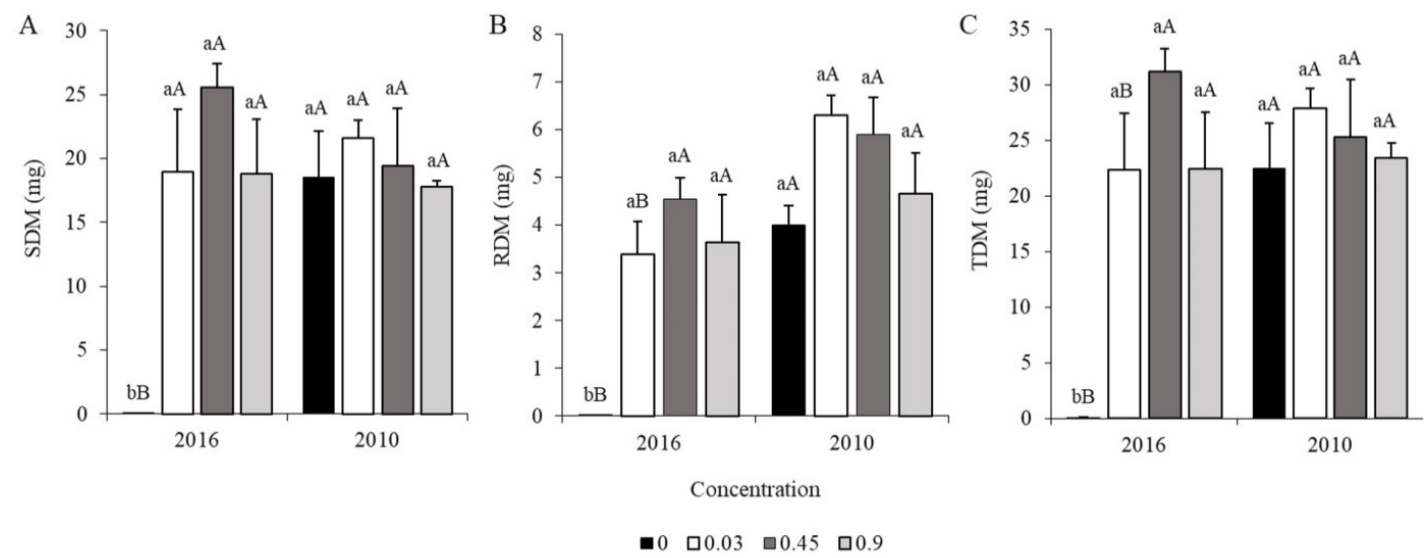

Figure 4. Effect of the interaction on shoot dry matter - SDM (A), root dry matter - RDM (B) and total dry matter - TDM (C) of Passiflora cincinnata seedlings obtained from seeds harvested in different periods and subjected to different concentrations of $\mathrm{GA}_{4+7}+\mathrm{N}$-(phenyl methyl)-aminopurine.

*Means followed by the same letter do not differ. Lowercase letters compare the concentrations for each harvest year. Uppercase letters compare the means of the concentrations between the harvest years.

All variables differed in the control treatment, with unsatisfactory results for the seeds harvested in 2016, demonstrating that this species needs previous treatment to overcome the dormancy of physiological nature, especially in recently harvested seeds. Gibberellins act in the synthesis of specific proteins and RNA in germination, associated with dormancy breaking and hydrolysis of reserves. Cytokinins play an important role in the promotion of radicle growth, besides acting in the control of cell division and elongation and in the regulation of the level of active inhibitors in the seeds, allowing them to become more sensitive to the action of the gibberellins (LEWAK, 2011; CEMBROWSKA-LECH; KEPCZYNSKI, 2016).

The results obtained in the present study demonstrate that Passiflora cincinnata seeds can be stored in cold chamber for a period of six years with maintenance of dormancy, which is important information for the conservation of germplasm in genetic improvement programs of this crop. Thus, the use of $\mathrm{GA}_{4+7}+\mathrm{N}$-(phenyl methyl)-aminopurine is efficient to overcome the dormancy of recently harvested seeds at the concentration of $0.03 \%$.

Most of the analyzed variables showed the best results at the concentrations $0.03 \%$ and $0.45 \%$. It should be pointed out that the concentration
$0.03 \%$ of $\mathrm{GA}_{4+7}+\mathrm{N}$-(phenyl methyl)-aminopurine is the most indicated to overcome dormancy in Passiflora cincinnata, both in recently harvested seeds and stored seeds, because the concentrations higher than $0.03 \%$ did not differ statistically for most variables evaluated. Thus, the product can be used to overcome the dormancy of Passiflora cincinnata seeds, even when recently harvested, because the results are similar to those of seeds stored for six years.

\section{CONCLUSIONS}

$\mathrm{GA}_{4+7}+\mathrm{N}$-(phenyl methyl)-aminopurine is recommended to overcome dormancy of Passiflora cincinnata in recently harvested seeds (2016) and increase the emergence of seedlings from seeds stored for six years in cold chamber (2010).

The $\mathrm{GA}_{4+7}+\mathrm{N}$-(phenyl methyl)aminopurine concentration of $0.03 \%$ can be used in the dormancy breaking of recently harvested seeds and potentiates the vigor of seeds stored for six years.

Passiflora cincinnata seeds remain physiologically viable for six years and their emergence is potentiated by the use of the growth regulator $\mathrm{GA}_{4+7}+\mathrm{N}$-(phenyl methyl)-aminopurine.

RESUMO: O tratamento de sementes com reguladores de crescimento pode superar a dormência das sementes, aumentar o vigor e o desenvolvimento das mudas. O objetivo desta pesquisa foi avaliar o efeito de diferentes concentrações de GA4 + 7 + N- (fenilmetil) -aminopurina na quebra de dormência de sementes de Passiflora cincinnata 
recentemente colhidas e armazenadas por seis anos. O estudo foi conduzido em uma estufa na Embrapa Mandioca e Fruticultura, em delineamento inteiramente casualizado, em esquema fatorial 2 x 4, com os seguintes fatores: ano de colheita de sementes (2010 e 2016) e promotor de emergência $\mathrm{GA}_{4}+7+\mathrm{N}$ - (fenilmetil) - aminopurina em quatro concentrações $(0 \% ; 0,03 \%$; $0,45 \%$ e $0,90 \%)$, com 4 repetições de 25 sementes. Foram avaliados a porcentagem de emergência, a primeira contagem, o índice de velocidade de emergência, o número de folhas, o comprimento da raiz, o diâmetro do caule, a matéria seca da parte aérea, das raízes, total e a relação raiz/parte aérea. $\mathrm{O} \mathrm{GA}_{4+7}+\mathrm{N}-($ fenilmetil) aminopurina é recomendado para superar a dormência de Passiflora cincinnata em sementes recentemente colhidas (2016) e aumenta a emergência de sementes armazenadas por seis anos em câmara fria. A concentração do promotor de emergência de $0,03 \%$ pode ser usada para superar a dormência em sementes recentemente colhidas e potencializa o vigor das sementes armazenadas durante seis anos. As sementes de Passiflora cincinnata permanecem fisiologicamente viáveis por seis anos e seu vigor é potencializado pelo uso de $\mathrm{GA}_{4+7}+\mathrm{N}$ - (fenilmetil) - aminopurina.

PALAVRAS CHAVES: Conservação. $\mathrm{GA}_{4+7}+\mathrm{N}$ - (fenilmetil) - aminopurina. Maracujá. Germinação.

\section{REFERENCES}

AMARO, A. C. E.; ZUCARELI, V.; MISCHAN, M. M.; FERREIRA, G. Combinações entre GA4+ 7+ N(fenil metil)-aminopurina e ethephon na germinação de sementes de Passiflora cincinnata Mast. Revista Brasileira de Sementes, v. 31, n. 1, p. 195-202, 2009. https://doi.org/10.1590/S0101-31222009000100022

BRASIL. Ministério da Agricultura, Pecuária e Abastecimento. Regras para análise de sementes. Ministério da Agricultura, Pecuária e Abastecimento. Secretaria de Defesa Agropecuária. Brasília, DF: MAPA/ACS, 2009. 395p. Link: http://www.agricultura.gov.br/assuntos/insumos-agropecuarios/arquivos-publicacoesinsumos/2946_regras_analise_sementes.pdf

CEMBROWSKA-LECH, D.; KEPCZYNSKI, J. Gibberellin-like effects of KAR1 on dormancy release of Avena fatua caryopses include participation of non-enzymatic antioxidants and cell cycle activation in embryos. Planta, v. 243, n. 2, p. 531-548, 2016. https://doi.org/10.1007/s00425-015-2422-1. Epub 2015 Nov 2.

FREITAS, J. C. de O.; PIO VIANA, A.; SANTOS, E. A.; PAIVA, C. L.; SILVA, F. H. DE L.; AMARAL JR. A. T. DO.; SOUZA, M. M.; DIAS, V. M. Resistance to Fusarium solani and characterization of hybrids from the cross between P. mucronata and P. edulis. Euphytica, v. 208, n. 3, p. 493-507, 2016. Link: https://link.springer.com/article/10.1007/s10681-015-1588-8

GUPTA, R.; CHAKRABARTY, S. K. Gibberellic acid in plant: still a mystery unresolved. Plant Signaling and ehaviour, v. 8, n. 9, p. e25504, 2013. https://doi.org/10.4161/psb.25504. Epub 2013 Jun 28

JESUS, O. N. de.; OLIVEIRA, E. J. de.; FALEIRO, F. G.; SOARES, T. L.; GIRARDI, E. A. Descritores morfoagronômicos ilustrados para Passiflora spp. 1. Ed. Brasília -DF, Embrapa, 2016, 122 p.

JUNGHANS, T. G.; JESUS, O. N. Passiflora cincinnata Mast. In: JUNGHANS, T. G. Guia de plantas e propágulos de maracujazeiro. 1. Ed. Embrapa Mandioca e Fruticultura, Cruz das Almas, 2015, p. 27.

JUNGHANS, T. G.; VIANA, A. J. C.; JUNGHANS, D. T. Armazenamento e tratamento mecânico na emergência de plântulas de Passiflora gibertii.. 1. Ed. Embrapa Mandioca e Fruticultura, Cruz das Almas, Brasil (Embrapa Mandioca e Fruticultura. Boletim de Pesquisa e Desenvolvimento, 45), 2010, 16p.

LEWAK, S. Metabolic control of embryonic dormancy in apple seed: seven decades of research. Acta Physiologiae Plantarum, v. 33, n. 1, p. 01-24, 2011. Link: https://link.springer.com/article/ 10.1007/s11738-010-0524-8.

KĘPCZYŃSKI, J.; BIAŁECKA, B.; LIGHT, M. E.; VAN STADEN, J. Regulation of Avena fatua seed germination by smoke solutions, gibberellin A 3 and ethylene. Plant Growth Regulation, v. 49, n. 1, p. 9-16, 2006. Link: https://link.springer.com/article/10.1007/s10725-006-0008-4. 
MAGUIRE, J. D. Speed of germination-aid in selection and evaluation for seedling emergence and vigor. Crop Science, v. 2, n. 1, p. 176-177, 1962. doi.org/10.2135/cropsci1962. 0011183X000200020033x

MELETTI, L. M. M.; FURLANI, P. R.; ÁLVARES, V.; SOARES-SCOTT, M. D.; BERNACCI, L. C.; AZEVEDO FILHO, J. A. Novas tecnologias melhoram a produção de mudas de maracujá. O agronômico, v. 54, n. 1, p. 30-33, 2002. Link: http://www.iac.sp.gov.br/publicacoes/agronomico/pdf/541_08t72.pdf

MELLO, A. M.; STRECK, N. A.; BLANKENSHIP, E. E.; PAPAROZZI, E. T. Gibberellic acid promotes seed germination in Penstemon digitalis cv. Husker Red. Hort Science, v. 44, n. 3, p. 870-873, 2009. Link: http://digitalcommons.unl.edu/cgi/viewcontent.cgi?article=1664\&context =agronomyfacpub

MORLEY-BUNKER, M. J. S. Seed coat dormancy in Passiflora species. Annual Journal Royal New Zealand Institute of Horticulture, v. 8, n. 1, p. 72-84, 1980. Link: http://agris.fao.org/agrissearch/search.do?recordID=NZ8203713

OCAMPO, J.; ARIAS, J. C.; URREA, R. Hibridação interespecífica entre espécies cultivadas e silvestres do gênero Passiflora L. Euphytica, v. 209, n. 1, p. 395-408, 2016.

OLIVEIRA, E. J.; SOARES, T. L.; BARBOSA, C. J.; SANTOS FILHO, H. P.; JESUS, O. N. Severidade de doenças em maracujazeiro para identificação de fontes de resistência em condições de campo. Revista Brasileira de Fruticultura, v. 35, n. 2, p. 485-492, 2013. https://doi.org/10.1007/s10681-016-1647-9

OLIVEIRA JÚNIOR, M. X. de; JOSÉ, A. R. S.; REBOUÇAS, T. N. H.; MORAIS, O. M.; DOURADO, F. W. N. Superação de dormência de maracujá-do-mato (Passiflora cincinnata Mast.). Revista Brasileira de Fruticultura v. 32, n. 2, p. 584-590, 2010. https://doi.org/10.1590/S0100-29452010005000045

PEREIRA, W. V. S.; VIEIRA, L. M.; RIBEIRO, L. M.; MERCADANTE-SIMÕES, M. O.; OLIVEIRA, T. G. S. Armazenamento de sementes de maracujazeiros. Pesquisa Agropecuária Tropical, v. 41, n. 2, p. 10-5216, 2011. Link: http://www.scielo.br/pdf/pat/v41n2/a17.pdf.

SANTOS, C. H.; NETO, A. J. C.; JUNGHANS, T. G.; JESUS, O. N. de; GIRARDI, E. A. Estádio de maturação de frutos e ácido giberélico na emergência e crescimento de Passiflora spp. Revista Ciência Agronômica, v. 47, n. 3, p. 481-490, 2016. Link:

http://www.ccarevista.ufc.br/seer/index.php/ccarevista/article/view/4049.

SANTOS, E. A.; PIO VIANA, A.; FREITAS, J. C. de O.; SILVA, F. H. de L.; EIRAS, R. R. M. Resistance to cowpea aphid-borne mosaic virus in species and hybrids of Passiflora: advances for the control of the passion fruit woodiness disease in Brazil. European Journal of Plant Pathology, v. 143, n. 1, p. 85-98, 2015. Link: https://link.springer.com/article/10.1007/s10658-015-0667-y.

SILVA, A. D. S.; OLIVEIRA, E. J. D.; HADDAD, F.; LARANJEIRA, F. F.; JESUS, O. N.; OLIVEIRA, S. A. S. D.; COSTA, M. A. P. DE C. FREITAS, J. P. X. D. Identification of passion fruit genotypes resistant to Fusarium oxysporum f. sp. passiflorae. Tropical Plant Pathology, v. 38, n. 3, p. 236-242, 2013. https://doi.org/10.1590/S1982-56762013005000008

SOARES, T. L.; JESUS, O. N. de; SOUZA, E. H. de; OLIVEIRA, E. J. Reproductive biology and pollen-pistil interactions in Passiflora species with ornamental potential. Scientia Horticulturae, v. 197, n. 1, p. 339-349, 2015. https://doi.org/10.1016/j.scienta.2015.09.045

ZHAO, YUNDE. Auxin biosynthesis and its role in plant development. Annual Review of Plant Biology, v. 61, n. 1, p. 49-64, 2010. https://doi.org/10.1146/annurev-arplant-042809-112308

ZUCARELI, V.; FERREIRA, G.; AMARO, A. C. E.; ARAÚJO, F. P. D. Fotoperíodo, temperatura e reguladores vegetais na germinação de sementes de Passiflora cincinnata Mast. Revista Brasileira de Sementes, v. 31, n. 3, p. 106-114, 2009a. https://doi.org/10.1590/S0101-31222009000300012 
ZUCARELI, V.; FERREIRA, G.; AMARO, A. C. E.; VAZIO, J. L. GA $4_{4+7}+$ N-(fenilmetil)-aminopurina na germinação de sementes de Passiflora cincinnata Mast. Revista Brasileira de Fruticultura, v. 31, n. 1, p. 216-223, 2009b. https://doi.org/10.1590/S0100-29452009000100030 